\title{
Non-timber forest products and their contribution to households income around Falgore Game Reserve in Kano, Nigeria
}

\author{
Muhammad Sabiu Suleiman ${ }^{1 *}$, Vivian Oliver Wasonga ${ }^{1}$, Judith Syombua Mbau', Aminu Suleiman²
} and Yazan Ahmed Elhadi ${ }^{1}$

\begin{abstract}
Introduction: In the recent decades, there has been growing interest in the contribution of non-timber forest products (NTFPs) to livelihoods, development, and poverty alleviation among the rural populace. This has been prompted by the fact that communities living adjacent to forest reserves rely to a great extent on the NTFPs for their livelihoods, and therefore any effort to conserve such resources should as a prerequisite understand how the host communities interact with them.

Methods: Multistage sampling technique was used for the study. A representative sample of 400 households was used to explore the utilization of NTFPs and their contribution to households' income in communities proximate to Falgore Game Reserve (FGR) in Kano State, Nigeria. Descriptive statistics and logistic regression analysis were used to analyze and summarize the data collected.

Results: The findings reveal that communities proximate to FGR mostly rely on the reserve for firewood, medicinal herbs, fodder, and fruit nuts for household use and sales. Income from NTFPs accounts for 20-60\% of the total income of most (68\%) of the sampled households. The utilization of NTFPs was significantly influenced by age, sex, household size, main occupation, distance to forest and market.

Conclusions: The findings suggest that NTFPs play an important role in supporting livelihoods, and therefore provide an important safety net for households throughout the year particularly during periods of hardship occasioned by drought. It is suggested that stakeholders should prioritize technical and financial support programs on agricultural value addition and handcrafts that would promote off-farm income generating activities, in addition, provision of alternative domestic cooking energy such as biogas in communities proximate to FGR in order to reduce pressure relating to fuelwood gathering from the forest, this will help to improve forest resources quality.
\end{abstract}

Keywords: Agricultural income, Collection, Conservation, Forest income, Game Reserve

\section{Introduction}

Forests provide products for different uses at households and industrial levels (Appiah 2009). These products are grouped into timber and non-timber products (NTFPs). Although timber products are highly valued worldwide, the NTFPs which play an important role in sustaining livelihoods of communities living around forest areas, but have been given minimum attention. Although NTFPs

\footnotetext{
*Correspondence: mssabiubuk@yahoo.com

'Department of Land Resource Management and Agricultural Technology, University of Nairobi, P.O. Box 29053, Loresho Ridge, Nairobi, Kenya Full list of author information is available at the end of the article
}

may not be the most important income generating products for local people living close to the forests, they contribute significantly to household income, food security, and household healthcare as well as, provision of multiple social and cultural values (Ojea et al. 2016; Endamana et al. 2016). In spite of these roles, a major challenge persists in the accurate evaluation of NTFPs as a revenue component for the livelihoods of indigenous people (Ngalim 2011). Furthermore, the importance of NTFPs in household income is not well known due to the absence of a systematic and rigorous data collection system at national level in many developing countries (FAO 2012). 
The role of NTFPs varies from one place to another depending on the economic and cultural contexts. In developed countries, for instance, NTFPs are usually used for cultural and recreational purposes, biodiversity conservation, and rural economic development. In developing countries, especially in Africa and Asia, they are mostly utilized for subsistence and income generation (Cocksedge 2006; Endamana et al. 2016). In the developing nations, NTFPs are therefore considered a safety net that fills the gaps due to a shortfall in agricultural production or other forms of emergencies (Shackleton and Shackleton 2004; Paumgarten 2005; Angelsen et al. 2014). As indicated by Agrawal et al. (2013), the NTFPs-based activities, if prioritized by the government and other stakeholders can be used to enhance the economic and social wellbeing of communities living in and around forestlands.

Economic estimates of approximately USD 90 billion per annum have been set for NTFPs worldwide, and approximately one-third of the same is consumed in the local economy without entering the market (Pimentel et al. 1997; Mahapatra and Tewari 2005). Most importantly, the NTFPs contribution to rural households' income is significant in many countries globally. For example, Shackleton et al. (2007) concluded that the shares of households' income from NTFPs revenue are sometimes equal to or more than the school teachers' minimum wages in Central and West Africa. They further reported that the NTFPs traders from the Democratic Republic of Congo earned between USD 16 and 160 per week while producers earned about $50-75 \%$ of that amount per week.

Previous workers have observed that rural households in Nigeria derived up to $80 \%$ of their incomes from the sales of NTFPs (Jimoh et al. 2013). In addition, Ogunsawa and Ajala (2002) and Zaku et al. (2013) reported that over $70 \%$ of the country's households depend directly on fuelwood as their main sources of energy, with daily consumption estimated at 27.5 million $\mathrm{kg} /$ day. Thus, harvesting and processing of NTFPs in many areas in the country have shifted from subsistence exploitation and sales at the local markets to international cross-boundary trade. For example, in the high forest zones of Eastern and Western Nigeria, harvesting of game meat and snails for sales are now major income generating activities almost all year round (Onuche 2011). While in the Savannah zone of Central and Northern Nigeria, honey, fuelwood, locust bean seeds, gum arabic, and charcoal production generate lots of incomes for the rural households (Jimoh and Haruna 2007; Jimoh et al. 2013). Similar contributions of NTFPs to rural wellbeing have been reported in other African countries including Kenya and Tanzania (Campbell 1991; Schaafsma et al. 2014 and Mbuvi and Boon 2009).
The world is grappling with a myriad of problems, including deepening poverty situations in many countries; especially the forest-dependent communities. These communities are mostly located in remote areas where most of the services and provisions are limited. Consequently, these communities find themselves heavily reliant on the natural resources within their proximity oftentimes. Therefore, forest resources, particularly the non-timber forest products (NTFPs) have been established as an essential source of livelihood for the majority of forestdependent communities among others. This study aimed at assessing the forest-people relationship in terms of the contributions of NTFPs to household's livelihoods and incomes; an important parameter that may guide policy formulation, practice, and management.

\section{Theoretical framework}

This study is conceived as forest dependency and household incomes in communities proximate to FGR. Resource use theory proposed by Firey (1960) was used as a framework to guide this study. The theory recognizes that people dependency over a given resource is a function of ecological, economic, and cultural factors that interacts with each other and plays a role in determining the level of interdependence between people and their environment. For instance, communities living close to protected areas in developing countries have historically depended on forest resources for their livelihoods' sustenance especially in times of hardship due to a shortfall in agricultural production and other forms of emergencies (Masozera and Alavalapati 2004; Mujawamariya and Karimov 2014). For most households in these communities, forests remain a bank of resources from which they derive additional income through consumption and sales of NTFPs (Brummit and Bachman 2010; Saha and Sundriyal 2012; Sunderland et al. 2014). Thus, sustainable extraction of NTFPs can be promoted as one of the rural development and biodiversity conservation strategies in forest rich areas (Saha and Sundriyal 2012). In Nigeria, the problem of high population density coupled with limited off-farm income generating activities in rural areas, households adjacent to forests commonly rely on forest resources to supplement their household income (Jimoh et al. 2013).

Theoretically, forest resource dependence has been conceptualized as a multifaceted construct with multiple temporal and spatial dimensions (Beckley 1998; Munanura et al. 2014). For example, forest resource utilization can be of different forms such as subsistence, commercial extraction of timber and NTFPs, tourism, education and research etc. These different levels of utilization and dependence operate and react differently at individual, community, national, and or international level (Munanura et al. 2014). This necessitates the need for site-specific analysis on community dependence on NTFPs that can be used to shape 
people-forest relationship for sustainable rural development and biodiversity conservation.

\section{Methods}

\section{Study area}

The study was conducted in three local government areas neighboring Falgore Game Reserve (FGR): Doguwa, Sumaila, and Tudun Wada in Kano, Nigeria. The FGR formerly known as Kogin Kano Game Reserve is located between longitudes $8^{0} 30^{\prime}$ and $8^{\circ} 50^{\prime}$ East and latitudes $10^{\circ} 46^{\prime}$ and $11^{\circ} 20^{\prime}$ North, $150 \mathrm{~km}$ South of Kano City. It has an estimated land area of 92,000 ha and is contiguous to Tiga artificial Lake to the north, and Lame Burra Game Reserve in Bauchi State to the Southeast (Yelwa 2008; BirdLife International 2007). The mean annual rainfall in FGR is $\approx 1000 \mathrm{~mm}$ and decreases to about $800 \mathrm{~mm}$ as geographical space shift northwards to Kano Metropolitan (Olofin 2000).

The FGR (Fig. 1) is a gallery forest with a high-density tree species and high floristic diversity found within the open Northern Guinea Savannah woodland vegetation type, though with elements of the Sudan Savannah in the northern tip (BirdLife International 2007). The vegetation of the study area is dominated by Isoberlinia, Khaya senegalensis, Vitex doniana, Anogeissus leiocarpus, Tamarindus indica, Detarium microcarpum, Afzelia africana, Anogeissus leiocarpa, Diospyros ebenum, Syzygium cordatum, and Pterocarpus erinaceus (Badamasi et al. 2010; BirdLife International 2007). African fan palm tree (Borassus aethiopum) and mango (Mangifera indica) dominate the river Kano bank which bisects the reserve into two forming part of the dense woodland. In addition, the reserve is habitat for different wild animal species (roan antelope, side stripped jackal, duikers, baboons, civet cat, hyena etc.), reptiles (frogs, snakes, monitor lizard, tortoises, turtles etc.), and birds (heron, hammer kob, ground horn bill, pigeons, abessynian rollers etc.). The presence of perennial grasses and shrubs throughout the year provides a condition suited for livestock grazing hence the reason for the dominance of pastoralists and agro-pastoralists that inhabit the area.

The density of the wild natural resources in the area has progressively dwindled over time (Badamasi et al. 2010). For instance, there was a general decrease in both

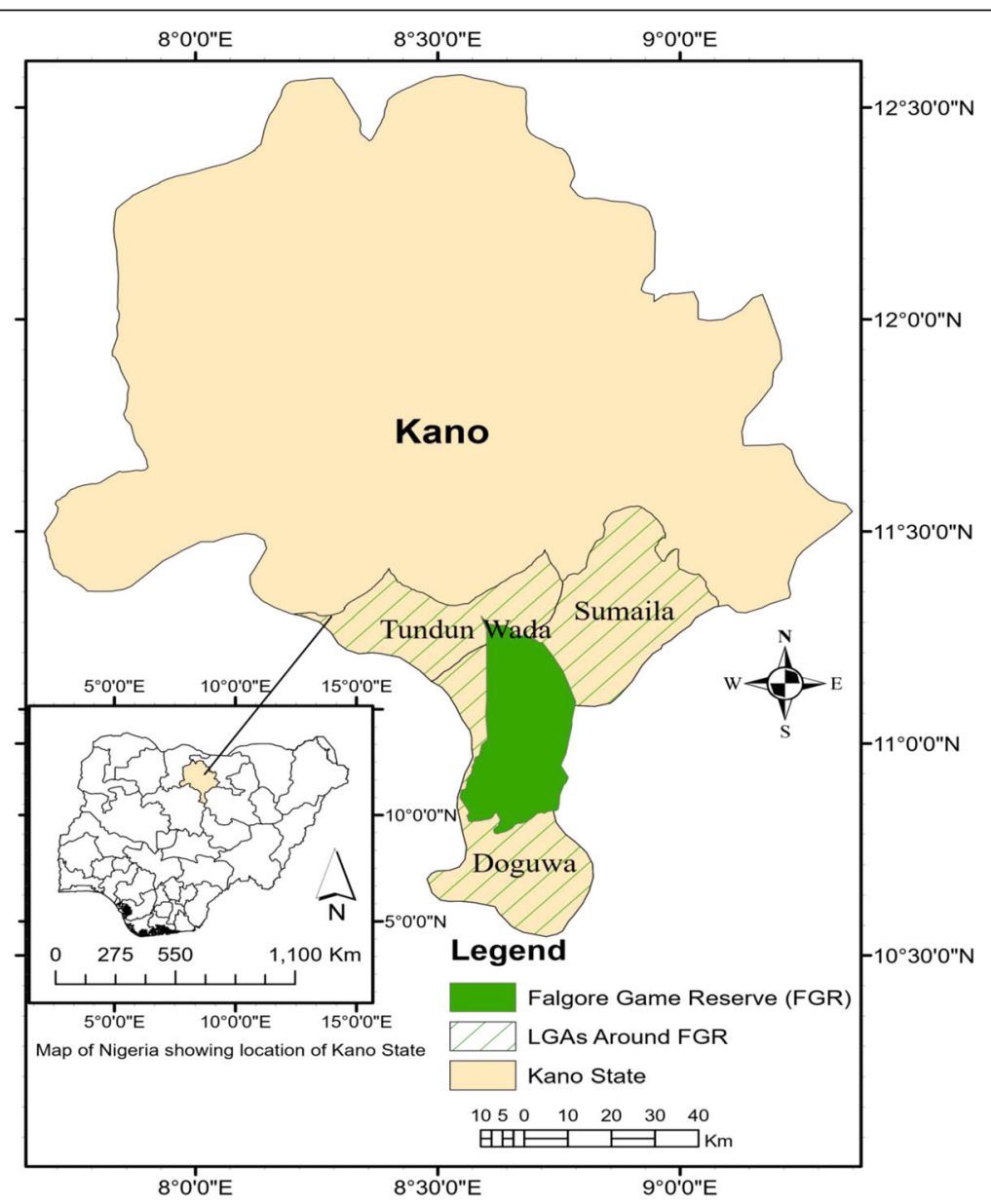

Fig. 1 Map of Kano, Nigeria indicating selected area for this study 
floral and faunal population of FGR between 1990 and 2006. This was attributed to frequent forest fire, fuelwood gathering, logging, hunting, and excessive exploitation of plant-based resources for subsistence and commercial purposes by local communities. These pose serious threats to plant population and composition, and animal biodiversity.

According to the 2006 census figures from national population commission of Nigeria, Kano State has a human population of 9,383,682, making it the most populous state in the country. With an annual growth rate of $3 \%$, the state human population is projected to reach 12,198,786 by 2016 (KNSG 2015). Specifically, the population density in communities around FGR is 200 persons $/ \mathrm{km}^{2}$, and more than a half of the inhabitants of the area are farmers involved in growing cereals, legumes, and vegetables. In addition to arable farming, livestock rearing and trade are major activities in the state (Daneji and Suleiman 2011); KNARDA 2006). Whereas the land is not a limiting factor in crop and livestock production in the study area, the majority of households remain food insecure because of the problem of soil infertility and traditional agronomic practices. This leads to high dependency on alternative sources, primarily the forest resources for households living in communities close to forestlands (Mohammed et al. 2010). The NTFPs including fuelwood, honey, and fruits are commonly traded along Jos-Kano highway in the study area, though collectors of gum arabic and game meat have to travel for approximately $150 \mathrm{~km}$ or more to access the market of these products. The major inhabitants of the State are the Hausa and Fulani ethnic groups.

\section{Sampling procedure}

Multistage sampling technique was used for this study. Three local government areas (LGAs), namely, Doguwa,
Sumaila, and Tudun Wada around Falgore Game Reserve area were purposively selected because of the existence of large portions of the reserve in their territories, as well as the high number of forest-dependent communities in the selected LGAs. At the second stage, three villages each from Sumaila (Ziria, Gomo, and Diwa) and Tudun Wada (Makwasa, Farurunruwa, and Nufawa) and four from Doguwa (Falgore, Yantabarmi, Dogon Kawo, and Sabuwar Kaura) were purposively selected. Generally, these villages were selected due to their high tendency to depend on non-timber forest resources from the reserve. They were also considered to have more stake in terms of access to and resource use rights over the available resources in the reserve as enshrined in the United Nation Convention on Biological Diversity of 1992 (CBD 1992). In total, ten villages were selected for the study (Table 1).

Proportional sampling was used for sample size determination using formula proposed by Yamane (1967). Briefly, appropriate sample size was computed taking into consideration the projected number of households in the selected communities and representations of each community. The adoption of this formula was informed by the desire to draw a representative sample from the target population and also to minimize sampling error and bias.

The formula is express as:

$$
n=\frac{N}{1+\left(e^{2}\right) N}
$$

Where

$n$ is the sample size to be estimated

$N$ is the definite population of the communities

$e$ is the significance level (0.05)

Using the above formula (Eq. 1), the sample size was computed ( $n=400$ respondents) out of 18,133 households in the study area as indicated in Table. 1 . The

Table 1 Sampling frame and sample size

\begin{tabular}{|c|c|c|c|c|}
\hline S/no. & Local government areas & Village & Sampling frame ${ }^{a}$ & Sample size \\
\hline \multirow[t]{4}{*}{1} & \multirow[t]{4}{*}{ Doguwa } & Falgore & 2535 & 56 \\
\hline & & Yantabarmi & 1250 & 27 \\
\hline & & Dogon Kawo & 1178 & 26 \\
\hline & & Sabuwar Kaura & 2090 & 46 \\
\hline \multirow[t]{3}{*}{2} & \multirow[t]{3}{*}{ Sumaila } & Ziria & 1544 & 34 \\
\hline & & Gomo & 2096 & 46 \\
\hline & & Diwa & 1780 & 39 \\
\hline \multirow[t]{3}{*}{3} & \multirow[t]{3}{*}{ Tudun Wada } & Makwasa & 1888 & 42 \\
\hline & & Farurunruwa & 2108 & 47 \\
\hline & & Nata'ala & 1664 & 38 \\
\hline Total & 3 LGAs & 10 & 18,133 & 400 \\
\hline
\end{tabular}

${ }^{\mathrm{a}}$ Data on the total number of households were obtained from the Kano State Government (KNSG 2015), Nigeria 
respondents were randomly selected using the random number table generator in Stata v13, from list of household heads provided in each village and confirmed using validated data from the Kano State Government (KNSG 2015).

\section{Data collection}

Data were collected from the sample households through interviews using a structured questionnaire and focus group discussions (FGD) guided by a checklist of questions. The data were collected from July to December 2015 by the corresponding author with the assistance of trained enumerators. The questions asked include but were not limited to: various NTFPs used by households, main actors involved in collection, value of NTFPs consumed and sold by the households, various sources of households' income, contribution of NTFPs to households' livelihoods. Others were demographic and socio-economic attributes of the respondents such as sex, age, household size, membership of the social group, contact with an extension agent, educational status, primary, and secondary occupation. The questionnaires were administered to household heads, however, in the absence of the head of household, a representative mostly the wife, eldest son, or the daughter was interviewed on his behalf.

Nine FGDs were carried out, three in each of the three LGAs selected for the study. Fifteen participants were selected for the FGDs including local leaders, community opinion leaders, and notable resource extractors of the major NTFPs from the reserve, representative of the Department of Agriculture, Forestry and Wildlife, representative of FGR official and representative of Kano State Ministry for Environment. Gender balance in terms of the participants of FGDs was observed in order to ensure that all sex and age classes were represented. The information elicited from FGDs were used to triangulate the household survey tools and for interpretations of results.

\section{Data analysis}

Both descriptive and analytical (inferential) statistics were used for data analysis. Descriptive statistics including the frequency, percentages, and bar chart were used to summarize the contribution of NTFPs to households' livelihoods, and partly the relative contribution of NTFPs to households' incomes. Prior to logistic regression analysis, a normality and multicollinearity tests were carried out. The data were found to be normally distributed, and multicollinearity problem was addressed by dropping a variable if found to be correlated with another variable(s) taking into consideration the relevance and power of the variables in explaining the dependent variable. Data collected during the FGDs were summarized using descriptive statistics and was further used to help draw inferences for the general results from household interview.

\section{Descriptive analysis of household income and non-timber forest products}

Household income was computed as the sum of income of all people in a particular household. It includes income from off-farm activities such as self-employment (trading, tailoring, carpentry, crafts etc.), formal employment (salary and wages), capital gains (money earned from interest on capital lent out and rent on building or dividend on shares), remittances (money sent by children and relatives), agricultural incomes (proceeds from sales of crops and livestock), and forest incomes (proceeds from sales of fuelwood, honey, fruit nuts, fodder, medicinal herbs, and gum arabic). Following Endamana et al. (2016), this computation was mathematically presented as follows:

$$
\mathrm{THI}=\mathrm{OFI}+\mathrm{AI}+\mathrm{FI}
$$

\section{Where:}

$\mathrm{THI}=$ total household income

OFI $=$ off-farm income

$\mathrm{AI}=$ agricultural income

$\mathrm{FI}=$ forest income

The per capita household monthly income was computed by taking the total gross household monthly income divided by the total number of family members dwelling together under the same roof (Endamana et al. 2016). The per capita daily household income was computed by taking per capita household monthly income divided by 30 days in a month.

Analysis of variance (ANOVA) was used to determine the mean differences between the households' incomes from agriculture, off-farm, and NTFPs incomes. The means were separated using the Fishers' least significant difference procedure as described by Hayter (1986). The hypothesis governing this test is stated below:

$H_{0}: \mu_{1}=\mu_{2}=\mu_{3} \ldots \ldots \ldots=\mu_{k} \quad$ (all $k$ households' income means from different sources are equal)

$H_{a}: \quad \mu_{1} \neq \mu_{2} \neq \mu_{3} \ldots \ldots \ldots . \ldots \mu_{k} \quad$ (all $k$ households' income means from different sources are not equal)

\section{Analytical model for the determinant of non-timber forest products collection and utilization}

Logistic regression analysis was used to determine factors that influence collection and utilization of NTFPs by households (Maddala 1983; Adesina et al. 2000). In this case, the NTFPs collection was hypothesized to be the end result of livelihood preference made by the household as influenced by it socio-economic and 
demographic attributes. Briefly, this relationship was represented as:

$$
Y_{i}=f\left(X_{i}, \varepsilon_{i}\right)
$$

The conceptual model based on logistic function is given as:

$$
Y_{\mathrm{ik}}=f\left(X_{i}\right)=\frac{e^{Z_{\mathrm{ik}}}}{1+e^{Z_{\mathrm{ik}}}}
$$

For $Z_{\mathrm{ik}}=X_{\mathrm{ik} \beta \mathrm{ik}}$ and $-\infty<Z_{\mathrm{ik}}<+\infty$

Where $Y_{i}$ is the dependent variable that takes a value of 1 for the $i$-th household who collect NTFP from FGR and 0 if otherwise, $X_{i}$ is a matrix of explanatory variables related to collection and utilization of NTFPs $\beta_{\text {ik }}$ are the vector of parameters to be estimated and $\varepsilon_{i}$ is the error term with a logistic distribution.

\section{Description of the variables used in the model}

The dependent variable $Y$ takes a value of 1 if the respondents utilized NTFPs from FGR and 0 if otherwise. Explanatory variables, assumptions, and their justifications are discussed below:

\section{Age}

Age was measured by the actual number of years of the household head. People across various age brackets can collect or utilize NTFPs from FGR. However, younger household heads may be more involved than elderly people, since the former may be more active and stronger, hence can cope with intensive labor demand of NTFPs collection and can always violate the forest protection rules. On the other hand, the aged household heads may be risk-averse in violating the rules of FGR protection, thus, they are less expected to collect NTFPs from the reserve.

\section{Sex}

Sex is a dummy variable that indexes the gender of the respondent, it carries a value of 1 for men and 0 for women. Men and women were partly engaged in different NTFPs enterprises based on socio-cultural context and therefore, utilized different resources from the forest. This is particularly true in traditional societies where males and females have specific roles and activities (Cavendish 2000; Arnold 2004; Davenport et al. 2012). For example, the collection of firewood and medicinal plants are jointly carried out in most part of Africa by both men and women (Bishop and LandellMills 2002; Vedeld et al. 2004; Agrawal et al. 2013), while the collection of honey and gum arabic are exclusively done by men. However, due to cultural barriers in the study area which limits women participation in NTFPs collection from the forest, men are more likely to take the risk of going into the forest compared to women. It is therefore hypothesized that maleheaded households are more likely to be more dependent on forest resources than female headed households.

\section{Household size}

Large families are also more likely to face lower percapita land availability and high dependency ratios for food requirements (Adesina et al. 2000; Mujawamariya and Karimov 2014). They may thus rely on forest resources around them because of the available family labor that can be utilized for NTFPs collection. It was hypothesized that household size is positively related to NTFPs collection and utilization.

\section{Occupation}

The main occupation represents the major economic activity engaged by the household head for cash income and subsistence. Because of the fewer number of livelihood options in rural areas that can supplement household income and food deficit, they are therefore expected to rely more on forest resources such as NTFPs. Households who are engaged in other sectors of the economy such as trading and formal employment are less likely to be dependent on NTFPs compared to their counterparts in the farming enterprise (Jimoh and Azeez 2002; Daneji and Suleiman 2011).

\section{Level of education}

The level of education attained by the household head is expected to influence the nature of his/her economic activity and consequently the level of his/her income. This is because education would make it easier for households to comprehend negative externalities and passive user values of natural resources (Muchapondwa 2003; Newton et al. 2016). It is assumed that the high level of education of respondents would lead to extraction of fewer forest products since education opens up alternative employment opportunities and diverts people from subsistence livelihoods activities such as the gathering of NTFPs from the forest reserve (Shively and Pagiola 1999; Newton et al. 2016).

\section{Farm size}

Farm size is defined as the total area of farmland owned by the household and is measured in hectares. Farm size plays an important role in crop production as it influences the quantity and availability of food in the household at any point in time. Households with limited farmland may not be able to produce adequate food for their families, hence, rely heavily on forest resources around them as their safety net, to complement food shortage. It was hypothesized that household heads with large farm size may not heavily depend on NTFPs 
collection from FGR as they may have enough food for their members and a surplus for sale.

\section{Membership to a social group}

Membership to a social group is a key factor that facilitates the flow of information among members of a social system as well as increasing social cohesion and willingness to set and strive for common goals. Household heads who are members of a social group are less likely to be involved in the illegal extraction of forest resources. This is because household heads that are well informed and belong to a social group are expected to distance themselves from any acts that may inflict externalities on others or that may have a legal implication. Thus, this study assumed that membership to a social group may negatively influence the collection of NTFPs from FGR.

\section{Distance to forest}

The NTFPs collection is expected to be influenced by the actual distance measured in kilometer(s) between the household heads' home and the FGR. This implies that the longer the distance of household home from FGR, the less likely for it to collect NTFPs from the reserve. This was confirmed by Gunatilake, (1998) and Mujawamariya and Karimov (2014), who noted that people living closer to the forest had a higher dependency on forest resources compared to those living far from the reserve who would have more difficulties accessing NTFPs due to high transportation costs and other untold hardship.

\section{Distance to market}

Distance to the nearest market is a continuous variable, measured as distance covered in kilometers from respondents' home to the nearest market. This variable is expected to positively or negatively influence the respondent NTFPs collection from FGR especially for those products that are collected mainly for sale. Respondents who live closer to the marketplace are more likely to collect and depend more on NTFPs compared to those who live far from the market place. Nevertheless, access to markets may open up better income generating activities thereby making people less dependent on forest resources (Masozera and Alavalapati 2004; Saha and Sundriyal 2012).

\section{Household income}

The level of households' income besides that of NTFPs greatly determines the kind of choices they make with regards to their livelihoods adaptation strategies. It is expected that households with higher income would choose to invest more in other sectors of the economy rather than relying on NTFPs collection. Furthermore, households with higher income usually have a strong purchasing power that enables them to buy more food to compensate for low harvest while the low-income households rely heavily on natural resource extraction from forestlands around them (Cavendish 2000; Vedeld et al. 2004).

\section{Results}

\section{Socioeconomic characteristics of the respondents}

The socioeconomic attributes of the respondents presented in Table 2. Briefly, the majority (76\%) of the sampled households were between the age of 20 and 49 years while those who are 50 years or older were $24 \%$. The mean age of all respondents was 38 years. Furthermore, the predominant household size was 610 members (45\%), and the household sizes $1-5$, and 11-15 were 29 and $17 \%$, respectively. The other household sizes were below $10 \%$ but the mean, minimum, and maximum household size for all respondents were 8,1 , and 21 persons, respectively (Table 2). With regards to farm size, the larger proportions of households have smaller land sizes including $<1.25$ ha (36\%), $1.25-2.24$ ha (29\%), and $2.25-3.24$ ha (23\%). Only $12 \%$ of all respondent have $\geq 3.25$ ha, and the overall average farm size for the sampled households under cultivation was 2 ha per household.

The gross monthly income of more than half $(53 \%)$ of the households ranged from USD 85-215 ( $\$ 26,000$ $65,000)$ whereas about a quarter $(25 \%)$ of the respondents had a monthly income of between USD 17-84. The mean household income for all the interviewed households was USD 165 ( 49,952$)$ per month, and the per capita daily household income indicates that $77 \%$ of individuals in the interviewed household were living on less USD 1.10 per day with an overall mean of USD 0.8 per person per household. It was confirmed that market access was easy for approximately $51 \%$ of the respondents who lives in less than $1 \mathrm{~km}$ to the nearest market while a total of $85 \%$ lived in $\leq 7.83 \mathrm{~km}$. The total range of distance covered to the nearest market for the forest fringes communities was $0.5-42 \mathrm{~km}$ with an average of $5 \mathrm{~km}$. Similarly, the average distance from home to Falgore Game Reserve for the 10 communities surveyed was $4 \mathrm{~km}$ although this range from 0.25 up to $10.25 \mathrm{~km}$. Over $40 \%$ travel less than $2.25 \mathrm{~km}$ and $64 \%$ travel up to $4.25 \mathrm{~km}$ to reach the FGR to collect NTFPs from the reserve (Table 2).

Whereas $86 \%$ of the interviewed household respondents were male, only $69 \%$ of all respondents have up to primary level of education. Approximately, 37\% were farmers and only $28 \%$ of all respondents depended primarily on NTFPs. Finally, while $63 \%$ of the respondents belong to at least one social group, $76 \%$ have the FGR as their main source of NTFP (Table 2). 
Table 2 Socioeconomic attributes of the respondents

\begin{tabular}{|c|c|c|c|c|c|}
\hline Household attributes class & & Frequency & Minimum & Maximum & Mean \pm STD \\
\hline \multirow[t]{5}{*}{ Age of household head (years) } & $20-29$ & $90(23)$ & 25 & 65 & $38 \pm 11$ \\
\hline & $30-39$ & $128(32)$ & & & \\
\hline & $40-49$ & $86(21)$ & & & \\
\hline & $50-59$ & $74(19)$ & & & \\
\hline & $60-69$ & $22(5)$ & & & \\
\hline \multirow[t]{5}{*}{ Household size (persons) } & $1-5$ & $114(29)$ & 1 & 21 & $8 \pm 4.44$ \\
\hline & $6-10$ & $180(45)$ & & & \\
\hline & $11-15$ & $70(17)$ & & & \\
\hline & $16-20$ & $34(8)$ & & & \\
\hline & $21-25$ & $2(1)$ & & & \\
\hline \multirow[t]{5}{*}{ Farm size (ha) } & $0.25-1.24$ & $145(36)$ & 0.25 & 5 & $2 \pm 0.87$ \\
\hline & $1.25-2.24$ & $117(29)$ & & & \\
\hline & $2.25-3.24$ & $91(23)$ & & & \\
\hline & $3.25-4.24$ & $32(8)$ & & & \\
\hline & $4.25-5.24$ & $15(4)$ & & & \\
\hline \multirow[t]{7}{*}{ Household income (USD) ${ }^{\mathrm{a}}$} & $17-84$ & $100(25)$ & 17 & 422 & $165 \pm 10$ \\
\hline & $85-150$ & $109(28)$ & & & \\
\hline & $151-215$ & $101(25)$ & & & \\
\hline & $216-285$ & $44(11)$ & & & \\
\hline & $286-350$ & $21(5)$ & & & \\
\hline & $351-415$ & $8(2)$ & & & \\
\hline & $\geq 416$ & $17(4)$ & & & \\
\hline \multirow[t]{5}{*}{ Per capita daily household income (USD) ${ }^{a}$} & $0.11-0.60$ & 193(48) & 0.1 & 3.79 & $0.8 \pm 0.03$ \\
\hline & $0.61-1.10$ & 115(29) & & & \\
\hline & $1.11-1.60$ & $42(11)$ & & & \\
\hline & $1.61-2.10$ & $25(6)$ & & & \\
\hline & $\geq 2.11$ & $25(6)$ & & & \\
\hline \multirow[t]{7}{*}{ Distance from home to market (km) } & $\leq 1$ & 205(51) & 0.5 & 42 & $5 \pm 1.6$ \\
\hline & $1.01-7.83$ & $137(34)$ & & & \\
\hline & $7.84-14.67$ & $16(4)$ & & & \\
\hline & $14.68-21.50$ & $12(3)$ & & & \\
\hline & $21.51-28.33$ & $15(4)$ & & & \\
\hline & $28.34-35.17$ & $7(2)$ & & & \\
\hline & $\geq 35.18$ & $8(2)$ & & & \\
\hline \multirow[t]{5}{*}{ Distance from home to FGR } & $0.25-2.25$ & $158(40)$ & 0.25 & 9 & $4 \pm 1$ \\
\hline & $2.26-4.25$ & $97(24)$ & & & \\
\hline & $4.26-6.25$ & $89(22)$ & & & \\
\hline & $6.26-8.25$ & $49(12)$ & & & \\
\hline & $8.26-10.25$ & $7(2)$ & & & \\
\hline \multirow[t]{2}{*}{ Sex } & Male & $344(86)$ & & & \\
\hline & Female & $56(14)$ & & & \\
\hline \multirow[t]{4}{*}{ Educational level } & Informal education & $135(34)$ & & & \\
\hline & Primary & $140(35)$ & & & \\
\hline & Secondary & $97(24)$ & & & \\
\hline & Tertiary & $28(7)$ & & & \\
\hline
\end{tabular}


Table 2 Socioeconomic attributes of the respondents (Continued)

\begin{tabular}{lll}
\hline Main occupation & Farming & $149(37)$ \\
& Trading & $74(19)$ \\
& NTFPs extraction & $114(28)$ \\
& Employment & $9(2)$ \\
Craft and artisans & $54(14)$ \\
Membership of a social group & Member & $252(63)$ \\
Main source of NTFPs & Non-member & $148(37)$ \\
& FGR & $304(76)$ \\
& Own farm & $62(16)$ \\
\hline
\end{tabular}

Source: survey by authors, 2015, figure in parentheses are percentage

${ }^{a}$ USD to Naira exchange rate at the time of conversion was USD $1=\mathrm{N} 300$

Non-timber forest products utilized by households and collectors based on gender typology

Harvesting and selling of NTFPs are some of the major income generating activities among households living in communities proximate to FGR. Figure 2 shows the main non-timber forest products collected by households from FGR. The results indicate that fuelwood (99\%) and medicinal herbs (84\%), fruit nuts (80\%), and fodder (67\%) were the most commonly collected NTFPs by households in the study area.

The gender typology for NTFPs collection in Falgore Game Reserve is as shown in Fig. 3. The results revealed that all the household members (men, women, boys, and girls) were involved in the collection of NTFPs. However, men were the dominant extractors of NTFPs. Most of the collectors of fuelwood (92\%), gum arabic (88\%), fruit nuts $(88 \%)$, fodder (96\%), honey (98\%), and medicinal herbs (99\%) were men. In addition, most of the women were also engaged in the collection of herbal medicine (77\%) and fruit nuts (38\%). Young men were also found to be actively involved in the collection of fuelwood (68\%), fruit nuts (76\%), fodder (58\%), and gum arabic (35\%), whereas young women were mainly involved in the collection of fuelwood (65\%) and fruit nuts (36\%). This implies that NTFPs extraction is male dominated activity in the study area.

\section{Contribution of non-timber forest products to households' income}

Percentage share of household income by sources

The percentage contribution of agricultural, off-farm, and NTFPs incomes to total household incomes is shown in Fig. 4. The result indicates that communities proximate to FGR like in any other rural settings of Nigeria, agriculture incomes was the major source of income for the sampled respondents accounting for about $47 \%$ of their total household incomes. The NTFPs income (proceeds from sales of fuelwood, honey, gum arabic, medicinal herbs, fruit nuts, and fodder) accounts for $30 \%$ of the total household incomes in the study area. This finding suggests that activities in the area of NTFPs contribute significantly to household income and thus can act as a safety net during the period of hardship and other emergencies.

On the contrary, the low contribution of off-farm incomes to the total household incomes recorded in this

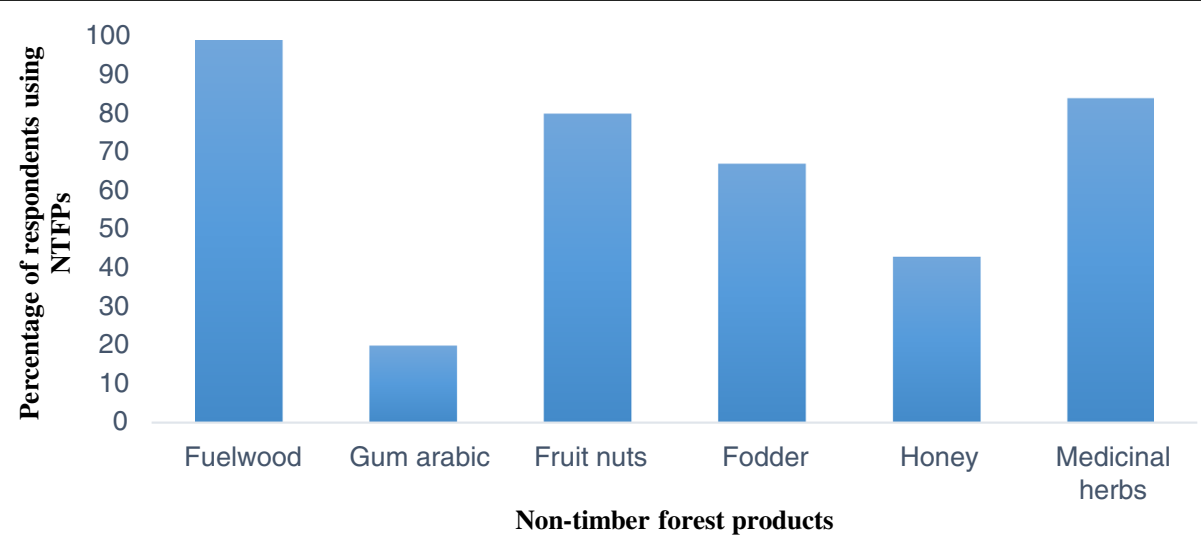

Fig. 2 Main non-timber forest products collected by the households from Falgore Game Reserve 


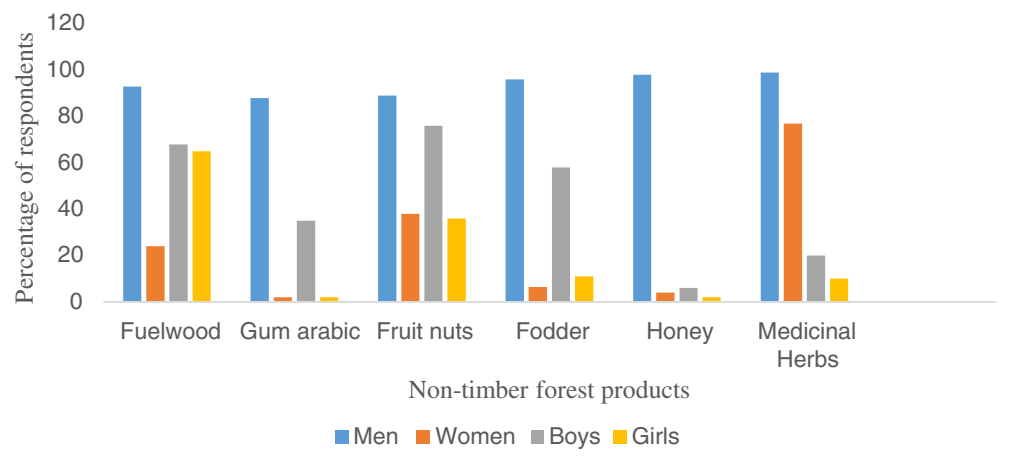

Fig. 3 Collection of non-timber forest products by gender

study indicated that off-income activities in rural Nigeria are low-income generating activities which are characterized as low-productivity hence may not significantly contribute to rural livelihoods (Timothy 2011).

\section{Percentage contribution of non-timber forest products to household incomes}

The percentage contribution of NTFPs to household incomes per month is presented in Fig. 5. The result revealed that $45 \%$ of the interviewed households derived between 20.5 and $40.5 \%$ of their total incomes from NTFPs whereas 22\% approximately derived between 41 and $60.5 \%$ of their total household incomes from sales of NTFPs. Meanwhile, only $2 \%$ of all the interviewed household raised more than $80.5 \%$ of their incomes from NTFPs-based enterprises in the study area. This finding implies that NTFPs constitutes an important component of the rural households' economy as they account for one-third of the total households' income in the study area.

\section{Mean difference of households' income by sources}

Multiple comparisons of various sources of household income using ANOVA are presented in Table 3. The

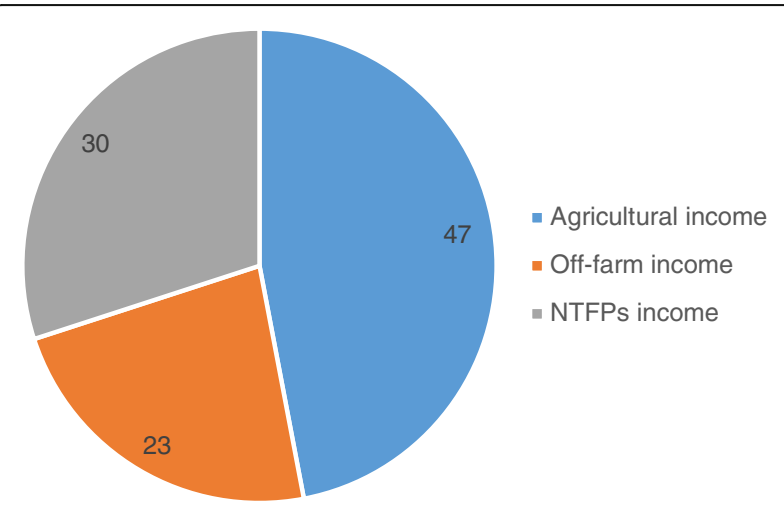

Fig. 4 Percentage contribution of agriculture, off-farm, and nontimber forest products incomes to the total household income result shows that the average monthly incomes of the households from sales of crop and livestock was significantly $(P<0.01)$ higher than that from NTFPs and offfarm incomes. Similarly, the average incomes derived from sales of NTFPs were significantly higher $(P<0.05)$, than off-farm incomes.

\section{Socio-economic and demographic factors influencing household utilization of non-timber forest products}

Factors that influenced household collection and utilization of NTFPs in FGR are presented in Table 4. The logistic regression model has an explanatory power that explained the total variation in the dependent variable with an overall fitness of $\left(\chi^{2}\right.$ value $=113.65, P<$ 0.01 ), in other words, none of the independent variables were zero, thus the null hypothesis was rejected. In addition, the Pseudo $R^{2}(0.25)$ indicates that $25 \%$ of the total variation in the dependent variable were explained by the independent variables fitted in the model. Thus, these variables can be used as explanatory variables for further studies on NTFPs collection and utilization elsewhere. Furthermore, sex and household size have a positive and significant $(P \leq 0.01)$ influence on households' collection and utilization of NTFPs. On the contrary, household members' ages, main occupation, distances to FGR and distance to main market and farm size all significantly influenced the households' utilization of NTFPs negatively $(P \geq 0.01)$ (Table 4$)$.

\section{Discussion}

The collection of NTFPs significantly contributes to the livelihoods status of the household living around FGR. This can be seen from Fig. 2 as the majority of the households collect fuelwood, fodder, fruit nuts, and medicinal herbs from the reserve. These findings generally imply that Nigeria's forest resource which is mostly under state management is faced with the problem of overexploitation by locals due to poor implementation of protection rules for most protected areas as well as poor investment in the forestry sub-sector by the government. 


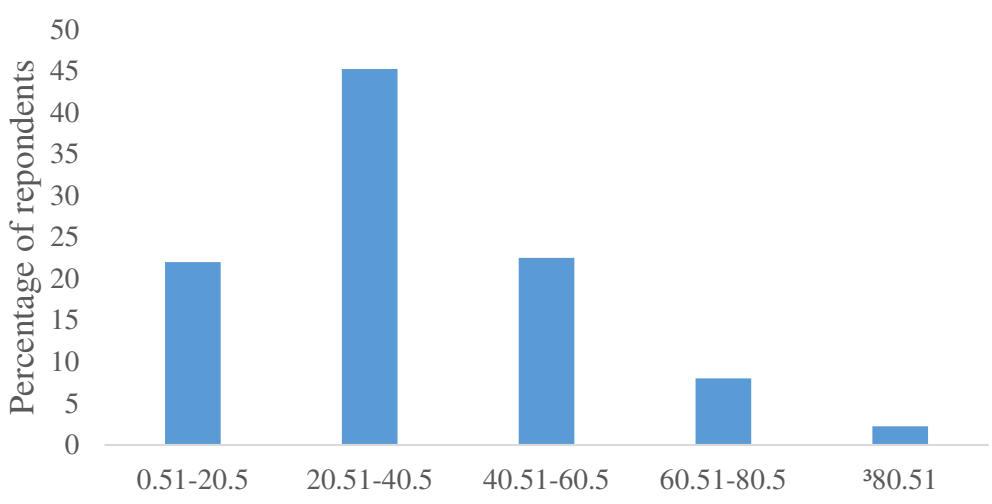

Percenatge of households' income derived from NTFPs

Fig. 5 Percentage contribution of non-timber forest products to the total household income

This was also reported by Meduna et al. (2009) that the lapse of the management of protected areas in Nigeria has led to encroachment by farmers and pastoralists who usually derive a significant part of their livelihoods from the protected areas. As indicated by Ojo (2004) and Shackleton et al. (2007), communities proximate to forestlands in Africa extract NTFPs from the forests irrespective of management regime or property right.

The increasing demand for NTFPs for subsistence and cash income generation has been reported in many developing countries (Ahenkan and Boon 2011; Shackleton et al. 2011; Steele et al. 2015), aggravated by the poor returns from agriculture and other off-farm income activities. Hence, NTFPs providing plants are highly prone to overexploitation and/or disappearance. Looking at the NTFPs contribution to rural livelihoods, it would not be appropriate to restrict further access to forestlands in order to conserve woodland resources and biodiversity, this action would not only inflict untold hardship on forest-dependent communities but may also affect the attainment of sustainable development goals in Nigeria. The NTFPs are mostly utilized for subsistence rather than cash income, however, the cash from the sale of NTFPs account for $30 \%$ of the total household incomes in the study area. Approximately, $68 \%$ of the interviewed households raised up to $40 \%$ of their

Table 3 Multiple comparisons of mean household incomes from agriculture, off-farm, and non-timber forest products

\begin{tabular}{llcl}
\hline Comparison of household income source & Mean difference & S.E. \\
\hline Agriculture income & Off-farm income & 5764.3 & $201.8^{* * *}$ \\
& NTFPs income & 3408.1 & $180.6^{* * *}$ \\
Off-farm income & Agriculture income & -5764.3 & $201.8^{* * *}$ \\
& NTFPs income & -2356.2 & $179.0^{* *}$ \\
NTFPs income & Agriculture income & -3404.1 & $180.6^{* * *}$ \\
& Off-farm income & 2356.2 & $179.0^{* *}$ \\
\hline
\end{tabular}

Source: survey by authors, $2015 \mathrm{~F}$-value $=11.63^{* * *}$ significance level ${ }^{* * *}(1 \%),{ }^{* *}(5 \%)$ total incomes from sales of NTFPs. This implies that the NTFPs contribution to households' income and therefore the role they play in providing safety net to forest proximate communities is of paramount importance especially to those households that has limited access to complementary economic opportunities. The findings of the current study corroborate those of Malleson et al. (2014), who reported that NTFPs and farm incomes were the major components of households' incomes in Nigeria and Cameroun. They also report higher income from NTFPs among households in remote areas than those living in the towns, which they attributed to lack of alternative sources of income among the former making them rely more on the sale of NTFPs. Thus, there is a need for policy reforms that will enhance people-forest relationship in Nigeria.

The logistic regression results support the widely accepted view that household participation in income generating activities is strongly influenced by their social, economic, and cultural status. However, these influences are mostly site specific and are not necessarily generalizable to all socio-economic conditions and geographical locations (Belcher Schreckenberg 2007; Coulibaly-Lingani et al. 2009). In the current study collection and utilization of households from FGR are influenced by the age of household heads, sex, household size, farm size, and distances from home to FGR and market outlet. It is evident from this finding that maleheaded households and those with large family size are more involved in NTFPs collection in the study area. Culturally, in the northern part of Nigeria, men are the major providers and contributors of the family needs and primary welfare depend on them, hence, the need for them to participate more in subsistence and cash income generating activities compared with their women counterparts. Furthermore, cultural and religious norms in most communities in northern Nigeria restrict women from entering forests as well as participation in physical outdoor activities such as collection of forest products. 
Table 4 Factors influencing household's collection and utilization of non-timber forest products

\begin{tabular}{lcccc}
\hline Household attributes & Coefficient & Standard error & $z$ & $\begin{array}{c}\text { Marginal effects of } \\
\text { NTFPs collection } \\
\text { and utilization }\end{array}$ \\
\hline Constant & 3.3124 & $0.39^{* * *}$ & $-6.73^{* * *}$ & $4.13^{* * *}$ \\
Age & -0.0984 & 0.0146 & $2.53^{* * *}$ & -0.1494 \\
Sex & 1.8195 & 0.4406 & $3.02^{* * *}$ & 0.3724 \\
Household size & 0.0899 & 0.0355 & 1.09 & 0.0137 \\
Occupation & 0.2604 & 0.0861 & $-3.26^{* *}$ & 0.0396 \\
Educational level & 0.1649 & 0.1506 & -0.50 & -0.0251 \\
Farm size & -0.4299 & 0.1318 & $-2.78^{* * *}$ & -0.6532 \\
Social group & -0.1475 & 0.2978 & $-2.64^{* * *}$ & -0.0221 \\
Distance to FGR & -0.1881 & 0.0172 & 1.50 & -0.2858 \\
Distance to market & -0.0455 & 0.0677 & $6.10 \mathrm{E}-06$ & -0.0691 \\
Income & $9.13 \mathrm{E}-06$ & $1.06 \mathrm{E}-06$ \\
\hline
\end{tabular}

Source: survey by authors, $2015 x^{2}=113.65^{* * *}, \log$ likelihood $=-168.11$, Pseudo $R^{2}=0.25, N=400$, significance level $* *(1 \%), * *(5 \%)$

Our findings also indicated that household size significantly influences the collection of NTFP by the respondents. This is because the larger family sizes are prone to have more labor available to support households' NTFPs extractions from nearby forestlands. Similar conclusion have been reached by Kabubo-Mariara and Gachoki (2008) who reported that families with large households who lived adjacent to forestlands in Kenya derived more resources from the common resources due to labor availability that can be spread across various collection activities. Based on the findings from the FGD, larger family sizes are attributable to polygamy and other socio-economic cum socio-cultural reasons, which support greater households' forest resources extractions. The greater majority of the respondents were youthful; an age range that is useful for coping with intensive labor associated with NTFPs collections. In our analysis, as the age increases, the tendency to engage in NTFPs reduces (Table 4; $P<0.01$ ). This inverse relationship observed between age of household head and collection of the NTFPs. Furthermore, because NTFPs collection activities in FGR need active individuals and are illegal, time-consuming and tedious, older people are discouraged from the risky practices compared with youth who are more willing to take risks of violating the rules governing extraction of NTFPs in the reserve. Cavendish (2000) had earlier stated that older people have difficulty carrying out arduous tasks related to NTFPs collection activities.

Additionally, land-poor households are more likely to collect NTFPs from the reserve in order to supplement their households' incomes and other basic needs. As indicated by Kabubo-Mariara and Gachoki (2008) who reported that land-poor families in Kenya were not able to produce enough food for their households and income needs, hence, largely depend on the forest products to complement their livelihoods. Furthermore, the finding of this study suggests that households living further away from market and FGR are less likely to collect NTFPs for household consumption and sales for cash income generation. This indicates that rural communities that live far from market facilities are expected to have limited livelihood options and may depend more on farming and extractive activities including but not limited to collection of NTFPs to meet their subsistence needs. In contrast, communities living closer to the market centers tend to have a wide range of business opportunities and therefore may be less interested in the collection of NTFPs. Perhaps, returns on labor and agricultural income are higher among communities that are closer to markets hence making them better off than their rural counterparts. This result supports the findings of Angelsen and Kaimowitz (1999) and Mulenga et al. (2011), that higher rural wages and greater off-farm employment opportunities reduce reliance on environmental resources. Therefore, assessing people-forest interaction among communities living in and around forestlands is a primary prerequisite for initiating any NTFP-based intervention in Nigeria.

\section{Conclusions}

Based on the findings of this study, it is clear that the FGR supports households' livelihoods through the provision of various NTFPs such as fuelwood, medicinal herbs, and fodder for livestock, honey, gum arabic, and fruit nuts for domestic use and sale for income generation. The FGR thus acts as a safety net, particularly when there is a shortfall in agricultural production, to minimize risk and also to fill the gap of food deficit in the study area. Although both men and women, boys and girls are involved in NTFPs collection in the study area, however, collection of NTFP is differentiated by gender. For instance, male participates more in honey 
and gum arabic extraction than their female counterparts. The NTFPs contribute significantly to household incomes in the study area as $68 \%$ of the households raise up to $40 \%$ of their income from these products.

It is recommended that stakeholders should prioritize technical and financial support programs that would promote off-farm income generating activities such as value addition for agricultural produce, handcraft etc. In the long-run, diversification into formal sector employment, coupled with education and skill development, is recommended. This will help reduce household overreliance on NTFPs for livelihoods and income generation. For effective conservation of NTFPs, strategies should take into consideration groups which were found to have more stake, such as the men and youth, in planning and implementing sustainable utilization and management of forest resources. In addition, interventions aimed at conserving the forest should consider both in-situ and exsitu conservation of the most utilized plants and trees used for medicines in order to relieve pressure on the wild stock. Provision of biogas and kerosene as alternative fuelwood and charcoal is recommended so as to reduce household overreliance on the forest wood plant.

\section{Abbreviations}

CBN: Central Bank of Nigeria; FAO: Food Agriculture Organization; FRN: Federal Republic of Nigeria; KNARDA: Kano Agricultural and Rural Development Authority; KNSG: Kano State Government; LGA: Local government area; NTFP: Non-timber forest products; WHO: World Health Organization

\section{Acknowledgements}

Study and research funding provided by Carnegie Foundation through RUFORUM is immensely appreciated.

\section{Authors' contributions}

SMS carried out the study and developed the manuscript. WVO, MJS, AS, and YEA read and made comments that improved the manuscript. All authors read and approved the final manuscript.

\section{Competing interests}

The authors declare that they have no competing interests.

\section{Ethics approval and consent to participate}

The ethics approval and consent was waived as it is not applicable for the study of this nature. However, we declare that the information on households attributes as contained in this study has been elicited with consents of the study participants for the purpose of this research and that the study has in no way used the defamatory word(s) against the study participants.

\section{Publisher's Note}

Springer Nature remains neutral with regard to jurisdictional claims in published maps and institutional affiliations.

\section{Author details}

'Department of Land Resource Management and Agricultural Technology, University of Nairobi, P.O. Box 29053, Loresho Ridge, Nairobi, Kenya. ${ }^{2}$ Department of Agricultural Economics and Extension, Bayero University Kano, Kano, Nigeria.
Received: 12 March 2017 Accepted: 7 June 2017

Published online: 17 July 2017

\section{Reference}

Adesina AA, Mbila D, Nkamleu GB, Endamana D (2000) Econometric analysis of the determinants of adoption of alley farming by farmers in the forest zone of southwest Cameroon. Agric Ecosyst Environ 80(3):255-265

Agrawal A, Cashore B, Hardin R, Shepherd G, Benson C, Miller D (2013) Economic contributions of forests, Background paper prepared for the United Nations Forum on Forests., http://www.un.org/esa/forests/pdf/session_documents/ unff10/EcoContrForests.(retrieved 15 August 2015)

Ahenkan A, Boon E (2011) Non-timber forest products (NTFPs): clearing the confusion in semantics. J Hum Ecol 33(1):1-9

Angelsen A, Jagger P, Babigumira R, Belcher B, Hogarth NJ, Bauch S (2014) Environmental income and rural livelihoods: a global-comparative analysis. World Dev 64:12-28

Angelsen A, Kaimowitz D (1999) Rethinking the Causes of Deforestation: Lessons from Economic Models. World Bank Res Obs. 14(1):73-98.

Appiah DO (2009) Personifying sustainable rural livelihoods in forest fringe communities in Ghana: a historic rhetoric? J FOOD AGRIC 7(3\&4):873-877

Arnold M (2004) Introduction. Forest Products, Livelihoods and Conservation. In: Kusters K, Belcher B (eds) Case studies of non-timber forest product systems, vol 1 - Asia. CIFOR, Bogor

Badamasi MM, Yelwa SA, AbdulRahim MA, Noma SS (2010) NDVI threshold classification and change detection of vegetation cover at the Falgore Game Reserve in Kano State, Nigeria. Sokoto J Soc Sci 2(2):174-194

Beckley TM (1998) The nestedness of forest dependence: a conceptual framework and empirical exploration. Soc Nat Resour 11:101-120

Belcher B, Schreckenberg K (2007) Commercialisation of non-timber forest products: a reality check. Dev Policy Rev 25(3):355-377

BirdLife International (2007) BirdLife's online World Bird Database: the site for bird conservation. http://www.birdlife.org/africa/partners/nigerianconservation-foundation-ncf

Bishop J, Landell-Mills N (2002) Forest environmental services: an overview. In: Bishop J, Pagiola S, Landell-Mills N (eds) Selling forest environmental services: market-based mechanisms for conservation and development. Earthscan, London

Brummit N, Bachman S (2010) Plants under pressure a global assessment: the first report of the IUCN sampled red list index for plants. Royal Botanic Gardens, Kew

Campbell JY (1991) Case studies in forest-based small-scale enterprises in Asia: Rattan match-making-handicrafts, Community Forestry Case Study, FAO, 4. FAO, Bangkok, p 93

Cavendish W (2000) Empirical regularities in the poverty-environment relationship of rural households: evidence from Zimbabwe. World Dev 28(11):1979-2003

CBD (1992) The convention on biological diversity. Secretariat of the Convention on Biological Diversity. United Nations Environment Programme, Montreal, Available from https://www.cbd.int/doc/legal/cbd-en.pdf. Accessed July 2014

Cocksedge W (2006) Incorporating non-timber forest products into sustainable resource management: an overview for resource managers. Royal Roads University, Victoria

Coulibaly-Lingani P, Tigabu M, Savadogo P, Oden PC, Ouadba JM (2009) Determinants of access to forest products in southern Burkina Faso. Forest Policy Econ 11(7):516-524

Daneji MI, Suleiman MS (2011) Accessibility and utilization of agricultural information among farmers in Wudil Local Government Area, Kano State, Proceedings of the 36th Annual Conference of the Nigerian Society for Animal Production (NSAP) held at Abuja 13th - 16th March., pp 652-654

Davenport NA, Shackleton CM, Gambiza J (2012) The direct use value of municipal commonage goods and services to urban households in the Eastern Cape, South Africa. Land Use Policy 29(3):548-557

Endamana D, Angu KA, Akwah GN, Shepherd G, Ntumwel BC (2016) Contribution of non-timber forest products to cash and non-cash income of remote forest communities in Central Africa. Int For Rev 18(3):280-295

FAO (2012) State of the World's Forests 2012. FAO, Rome, http://www.fao.org/3/ a-i3010e.pdf. Accessed July 2015

Firey W (1960) Man, mind and land; a theory of resource use. Free Press Glencoe (IL) 256

Gunatilake HM (1998) The role of rural development in protecting tropical rainforests: evidence from Sri Lanka. J Environ Manage. 53(3):273-292. 
Hayter AJ (1986) The maximum familywise error rate of Fisher's least significant difference test. J Am Stat Assoc 81(396):1000-1004

Jimoh SO, Azeez 10 (2002) Prospects of community participation in the management of shasha forest reserve, Osun State, Nigeria. In: Abu JE, Oni Pl, Popoola L (eds) Proceedings of the 28th Annual Conference of Forestry Association of Nigeria. Forestry and Challenges of Sustainable Livelihood, Akure, pp 208-216

Jimoh SO, Haruna EA (2007) Contributions of non-timber forest products to household food security and income around Onigambari forest reserve, Oyo State, Nigeria. J Environ Ext 6(1):28-33

Jimoh SO, Amusa TO, Azeez IO (2013) Population distribution and threats to sustainable management of selected non-timber forest products in tropical lowland rainforests of Southwestern Nigeria. J Forest Res 24(1):75-82

Kabubo-Mariara J, Gachoki C (2008) Forest Dependence and Household Welfare: Empirical Evidence from Kenya, CEEPA Discussion Paper No. 41

KNARDA (2006) Mission, vision and achievements of the special mass food production program. Kano state Ministry of Agriculture and Rural Development publication No. 31, Kano State, pp 2-10

KNSG (2015) National Population Commission, census report 2006 Kano State., pp 30-35

Maddala GS (1983) Limited dependent and qualitative variables in econometrics. Cambridge University Press, Cambridge

Mahapatra AK, Tewari DD (2005) Importance of non-timber forest products in the economic valuation of dry deciduous forests of India. Forest Policy Econ 7(3):455-467

Malleson R, Asaha S, Egot M, Kshatriya M, Marshall E, Obeng-Okrah K, Sunderland $\mathrm{T}$ (2014) Non-timber forest products income from forest landscapes of Cameroon, Ghana and Nigeria - an incidental or integral contribution to sustaining rural livelihoods? Int For Rev 16(3):261-277

Masozera MK, Alavalapati JRR (2004) Forest dependency and its implications for protected areas management: a case study from the Nyungwe Forest Reserve, Rwanda. Scand J For Res 19:85-92

Mbuvi D, Boon E (2009) The livelihood potential of non-wood forest products: the case of Mbooni Division in Makueni District, Kenya. Environ Dev Sustain 11(5):989-1004

Meduna AJ, Ogunjinmi AA, Onadeko SA (2009) Biodiversity Conservation Problems and their Implications on Ecotourism in Kainji Lake National Park, Nigeria. Journal of Sustainable Development in Africa. 10(4):59-73.

Mohammed SO, Gajere EN, Eguaroje EO, Shaba H, Ogbole JO, Mangut YS, Kolawole IS (2010) Spatio-temporal analysis of the national parks in Nigeria using geographic information system. IFE J Sci 15(1):159-166

Muchapondwa E (2003) The economics of community-based wildlife conservation in Zimbabwe (No. 130)

Mujawamariya G, Karimov AA (2014) Importance of socioeconomic factors in the collection of NTFPs: The case of gum arabic in Kenya. Forest Pol Econ 42:24-29

Mulenga BP, Richardson RB, Mapemba LD, Tembo G (2011) The contribution of non-timber forest products to rural household income in Zambia (No. 109887). Michigan State University, Department of Agricultural, Food, and Resource Economics

Munanura IE, Backman KF, Moore DD, Hallo JC, Powell RB (2014) Household poverty dimensions influencing forest dependence at Volcanoes National Park, Rwanda: an application of the sustainable livelihoods framework. Nat Resour 5(16):1031

Ngalim OY (2011) Revenue components and conflicts in the use of natural resources in the peripheral zone Northeast of Korup National Park. Unpublished Master's thesis, Department of Forestry, The University of Dschang, Cameroon, p 93

Newton P, Miller DC, Byenkya MAA, Agrawal A (2016) Who are forest-dependent people? A taxonomy to aid livelihood and land use decision-making in forested regions. Land Use Policy 57:388-395

Ogunsawa OY, Ajala OO (2002) Firewood crises in Lagos- implication on the suburban and rural ecosystem management, Proceeding of the 28th annual conference of Forestry Association of Nigeria at Akure, Ondo State. Nov. 4th - 8th., pp 257-264

Ojo LO (2004). The fate of a tropical rainforest in Nigeria: Abeokuta Sector of Omo Forest Reserve. GLOBAL NEST J. 6(2):116-130.

Ojea E, Loureiro ML, Alló M, Barrio M (2016) Ecosystem services and REDD: estimating the benefits of non-carbon services in worldwide forests. World Dev 78:246-261

Olofin EA (2000) Environmental hazards and sustainable development in Northern Nigeria'. In: Falola JA, Ahmed K, Liman MA, Maiwada A (eds) Issues in land administration and development in Northern Nigeria. Department of Geography, Bayero University, Kano, pp 207-220
Onuche P (2011) Non-timber forest products: a pathway for rural poverty reduction in Nigeria. Int J Econ Dev Res Investment 2(2):28-37

Paumgarten $F$ (2005) The role of non-timber forest products as safety-nets: a review of evidence with a focus on South Africa. GeoJournal 64(3):189-197

Pimentel D, McNair M, Buck L, Pimentel M, Kamil J (1997) The value of forests to world food security'. Hum Ecol 25(1):91-120

Saha D, Sundriyal RC (2012) Utilization of non-timber forest products in humid tropics: Implications for management and livelihood. Forest Pol Econ 14(1):28-40

Schaafsma M, Morse-Jones S, Posen P, Swetnam RD, Balmford A, Bateman IJ, Geofrey $V$ (2014) The importance of local forest benefits: economic valuation of non-timber forest products in the Eastern Arc Mountains in Tanzania. Glob Environ Change 24:295-305

Shackleton C, Shackleton S (2004) The importance of non-timber forest products in rural livelihood security and as safety nets: a review of evidence from South Africa. S Afr J Sci 100(11-12):658-664

Shackleton CM, Shackleton SE, Buiten E, Bird N (2007) The importance of dry woodlands and forests in rural livelihoods and poverty alleviation in South Africa. Forest Pol Econ 9(5):558-577

Shackleton S, Delang CO, Angelsen A (2011) From subsistence to safety nets and cash income: exploring the diverse values of non-timber forest products for livelihoods and poverty alleviation, Non-timber forest products in the global context. Springer Berlin Heidelberg, Berlin, pp 55-81

Shively G, Pagiola S (1999) Agricultural intensification, local labor markets, and deforestation in the Philippines. Environment and Development Economics $9(2): 241-266$

Steele MZ, Shackleton CM, Shaanker RU, Ganeshaiah KN, Radloff S (2015) The influence of livelihood dependency, local ecological knowledge and market proximity on the ecological impacts of harvesting non-timber forest products. Forest Pol Econ 50:285-291

Sunderland T, Achdiawan R, Angelsen A, Babigumira R, Ickowitz A, Paumgarten F, Shively $G$ (2014) Challenging perceptions about men, women, and forest product use: a global comparative study. World Dev 64:S56-S66

Timothy AT (2011) Rural non-farm incomes and poverty reduction in Nigeria. African Economic Research Consortium

Vedeld P, Angelsen A, Sjaastad E (2004) Counting on the environment: forest incomes and the rural poor, Paper \#98. The World Bank Environment Department, Washington, DC

Yelwa SA (2008) Broad-scale vegetation change assessment across nigeria from coarse spatial and high temporal resolution, A VHRR Data. Cuvillier Verlag, Gottingen, p 350

Yamane T (1967) Statistics, an introductory analysis, 2nd edn. Harper and Row, New York

Zaku SG, Tukur AA, Kabir A, Jimento IG (2013) Wood fuel consumption in Nigeria and the energy ladder: a review of fuelwood use in Kaduna State. J Pet Technol Altern Fuels 4(5):85-89

\section{Submit your manuscript to a SpringerOpen ${ }^{\mathcal{O}}$ journal and benefit from:}

- Convenient online submission

- Rigorous peer review

- Open access: articles freely available online

- High visibility within the field

- Retaining the copyright to your article

Submit your next manuscript at springeropen.com 